IJ§ER

ISSN: $2149-5939$
International Journal of Social Sciences and Education Research

Online, https://dergipark.org.tr/tr/pub/ijsser

Volume: 6(4), 2020

\title{
Perceptions of health workers in effective use of energy and prevention of technological pollution
}

\author{
Nurgül Erdal ${ }^{1}$
}

Received date: 28 / 09 / 2020

Accepted date: $29 / 11 / 2020$

\begin{abstract}
Energy sources are not unlimited in the world and energy sources that are not unlimited are consumed rapidly. Energy is very precious and is an essential tool for our survival. In the globalizing world, thanks to technological advances, many facilities have been created, but technological pollution is increasing and all living things are affected, along with humans. If we want to live in a healthy, happy and peaceful life on earth, we must save on energy use, increase the use of renewable energy and reduce technological pollution by using technological tools carefully. We can turn this into an advantage by making small changes in our daily life. In this study, Turkey's major cities, increasing the sensitivity of employees in health care, energy effectively and efficiently to ensure the use, reduce technological pollution and sustainable to create an environment and was conducted in order to create the livable world for future generations. 229 healthcare workers participated in the study by random questionnaire method and face to face questionnaire was applied. Demographic and effective use of energy and technological pollution scale were used in the survey. The collected data were analyzed with statistical package programs used in social sciences. Descriptive analyzes, T test and Anova tests were performed. When the efficient use of energy and technological pollution were compared with gender, no significant difference was found between them except for the technological pollution sub-dimension. Technological pollution average scores of men are higher than women. When the efficient use of energy and technological pollution are compared with marital status, there is no significant difference except for the efficient use of energy. It was observed that the average scores of singles in efficient use of energy were higher than those who were married. Efficient use of energy and technological pollution were compared with age range, education level and occupation, and a significant difference was found between the effective use of energy and the efficient use of energy, which is a sub-dimension of technological pollution, and education levels. No significant relationship was found in other comparisons. Necessary suggestions were made at the end of the study.
\end{abstract}

Keywords: Efficient Use of Energy, Technological Pollution, Environmental Awareness

\section{Introduction}

In the globalizing world; Energy resources have decreased due to the industrial revolution, the increase of industrialization, the rapid development of technology, the rapid increase of the population, various natural disasters, wars, exploitation and unconscious use of natural resources due to the uncontrolled consumption of energy resources. Globalization and the increase in the population of the world have increased energy consumption for both countries and the whole world, and accelerated technological pollution (Hill \& Thompson, 2006). The unconscious use of energy resources and the pollution caused by technology have created environmental problems and threatened all living creatures in the environment (Kaiser et al., 1999).

Various methods are used to solve the environmental problem. One of these is environmental awareness training (Çınar et al., 2008). The other is that one of the most important features of our age is the efficient planning of renewable energy resources and their transfer to future generations in order to minimize the economic and environmental damages of the increased energy

${ }^{1}$ Dr., Istanbul University-Cerrahpaşa Cerrahpaşa Faculty of Medicine Hospital. Istanbul, Turkey nurgul.erdal@istanbul.edu.tr 
Erdal, N. (2020). Perceptions of health workers in effective use of energy and prevention of technological pollution. International Journal of Social Sciences and Education Research, 6(4), 543-555.

consumption as a result of economic growth and urbanization (Kahraman, 2019). The increase in industrialization and the crowding of the population have increased the need for energy. In order to provide the necessary energy as the need increased, different energy sources were used. Various policies have been determined in order to benefit from energy resources effectively. While determining energy policies in a globalizing world, the use of energy types that minimize energy use and reduce environmental problems should be supported by policies (Saraç \& Bedir, 2012).

In today's world where energy consumption is increasing rapidly, energy saving is of great importance both in terms of protecting natural resources and reducing costs without reducing the comfort of life. Even today, the difference between the concept of energy saving and energy efficiency is emerging. While energy saving means giving up some uses or comfort, energy efficiency means using the same unit of energy more effectively. While technology makes human life easier, it also harms the environment. Technological pollution is caused by the negative effects of some technological devices on air, water and soil and affecting living life. The development of industry, industrial activities and technological needs that facilitate daily life have led to technological pollution and eventually to environmental problems (Kete et al., 2017). Environmental awareness is not limited to the natural environment, but also includes changes in the structure of society (Erdal et al., 2020). Protection of the natural environment is associated with sustainable development. Sustainable development, on the other hand, is not concerned with the present and involves conserving the resources needed to meet the needs of the next generation in the future. Sustainable development also means ensuring social solidarity, increasing economic capability and placing biological responsibility (Sarıkaya \& Kara, 2007).

The aim of this study is; Efficient use of limited energy resources and minimizing technological pollution, making the environment habitable and transferring it to future generations. In order to achieve this, it is to use the limited energy resources in the world effectively and efficiently, to know the technology that makes our life easier and to choose the ones that reduce pollution and energy. To know that there are other living beings on earth and to believe that they have the right to live, to make small changes in our lives, to change our habits and preferences, to raise awareness of those around us as a sensitive individual. We can see that human beings can overcome all kinds of difficulties and dangers with their wisdom and common sense (Özkoçak et al., 2017).

\section{Efficient use of energy}

Energy is one of the basic needs for people to continue their lives healthy, safe and comfortable. People use energy in heating, lighting, transportation, industry, all kinds of production and everywhere imaginable. Ecology is the science that examines the relationships between plants, soil, animals, humans and non-living elements that make up living elements (Atalay, 2013). The earth has renewable and non-renewable resources for human beings and other living creatures to survive and is an indispensable public space for living things. Resources in the environment are not unlimited and when used unconsciously, it causes various problems (Kete et al., 2017). Although the environmental problems started with the history of humanity, they started to emerge due to the labor force, urbanization and technological developments brought by the industrial revolution that started in England towards the eighteenth century and then spread to the whole world. Small workshops that existed before the industry gave way to factories, and most of the agricultural workers migrated to these regions to work despite poor wages and working conditions (Dağdemir, 2015). Increasing industrial activities in the twentieth century and the technological needs developing accordingly have brought important environmental problems (Kızılboğa \& Batal, 2012).

Copyright (C) by International Journal of Social Sciences and Education Research ISSN: 2149-5939 
Erdal, N. (2020). Perceptions of health workers in effective use of energy and prevention of technological pollution. International Journal of Social Sciences and Education Research, 6(4), 543-555.

Population growth, industrialization, urbanization, the development of production technologies, the change in consumer consumption habits, on the other hand, natural resources that started to become excessively polluted caused problems that the modern world did not encounter until that day. Increasing unconscious production and consumption activities, the use of fossil fuels as energy and the toxic gases emitted into the atmosphere have increased thoroughly as they pose a danger to many living things besides human beings. Since global warming and similar environmental risks are events that affect the whole world, common measures to be taken by countries have become a serious need (Y1lmaz et al., 2005). In the 21st century, providing safe and sustainable energy has become one of the most important problems in the world. It is very important that countries produce energy and use it efficiently, effectively and sustainably.

Due to global warming and increasing environmental problems, there has been a tendency towards renewable energy sources. Renewable energy sources, (Solar energy, wind energy, geothermal energy, hydraulic energy, sea wave energy, biomass). These energy sources are cleaner and more environmentally friendly energy sources for sustainable living, which allow the reduction of greenhouse gases (Saraç \& Bedir, 2012). The globalization of environmental problems and their threat to the world has caused panic in the whole world and changed their attitude towards naturel reducing waste and wastes that cause environmental pollution, recycling and reusing waste, developing environmentally friendly production technologies, using energy-saving products and ensuring that consumers prefer environmentally friendly products are necessary measures for the efficient use of energy. In addition, when supported by country policies, energy consumption will decrease and environmental pollution will be prevented.

Efficient use of energy and sustainability are important. The concept of sustainability used in many areas; It is a participatory process with a perspective that enables the careful use of all social, cultural, scientific, natural and human resources of the society and is in this view (Gladwin et al., 1995). The World Environment and Development Commission expresses sustainable development as "meeting the needs of today without preventing future generations from meeting their own needs" (Brundtland, 1987). It is the harmonious relationship between economic, social and environmental factors in order to manage sustainable development successfully. Today, effective environmental education is one of the solutions considered to protect the environment. Environmental education should include the whole society. It can be defined as developing environmental awareness in all segments of the society, gaining environmentally sensitive, permanent and positive behavioral changes and protecting natural, historical, cultural, socio-aesthetic values, ensuring active participation and taking part in solving problems (Nalçacı \& Beldağ, 2012).

\section{Technological pollution}

In order to solve the problems caused by globalization and the increase of urban population, solutions are tried to be found with information communication technologies instead of traditional policies. There are applications required by technology in many areas such as transportation, energy, water, health, security, which are indispensable for urban life (Örseli \& Akbay, 2019).

Today, pollution of nature concerns not only countries but the whole world. After the industrial revolution, pollution of water, soil and air started to concern people. Solid, liquid and gaseous wastes from sewers, factories and vehicles cause environmental pollution and make nature uninhabitable for all living things. The number of people who believe that technological development should be stopped due to this pollution is increasing day by day. Despite advances in technology, it is seen that the quality of life decreases as human activities increase in the world. But in some 
Erdal, N. (2020). Perceptions of health workers in effective use of energy and prevention of technological pollution. International Journal of Social Sciences and Education Research, 6(4), 543-555.

technical advances they can prevent degradation in the environment. When the negative effects of technological developments on the environment reached a visible level (inefficient soils, erosion, thinning of the ozone layer, etc.) people started to think (Es, 1995).

Technology concept; It is the implementation of innovations and developments in a way that makes human life easier. Technology does not always create pollution, and sometimes increasing and developing technology benefits the environment. For example, old technology production produces more energy, water and chemical waste. It also increases carbon dioxide emission and air pollution. As production technologies improve, using less energy and chemicals, technologies that use environmentally friendly chemicals also reduce the amount of waste from production, thus reducing environmental pollution (http://www.kutahyaninsesi.com). The rapidly increasing world population and urbanization increase the energy need and costs, cause a decrease in allnatural resources including water, and the countries give more importance and support to the studies on environmental technologies, energy production, transportation, building technologies, lighting, household appliances. It has led to the development of environmentally friendly technologies in order to increase the solutions that emphasize energy efficiency in many areas such as automotive and health.

Most of the technological products are powered by electricity. Electrically operated tools generate electromagnetic fields and affect the Human brain. The best example of these is mobile phones. Examples of electromagnetic fields are base stations, high-voltage lines, radio-TV transmitters and home electrical installations. In order to keep electromagnetic pollution at the lowest level, regulations regarding electromagnetic field exposures should be arranged (Çerezci \& Yener, 2016).

\section{Effective use of energy and technological pollution relationship}

The rapidly increasing world population and urbanization have increased the energy need and costs. In the world, the decrease in all-natural resources including water, the countries giving more importance and support to the studies on environmental technologies, the existence of solutions that emphasize energy efficiency in many areas such as energy production, transportation, building technologies, lighting, household appliances, automotive and health, environmental technologies has led to development (https://cevreonline.com).

As a result of industrialization, advances and developments in technology, the rapid increase in the world population, dependence on energy has increased rapidly and an important relationship has been observed between energy consumption and the development of countries. Studies have stated that energy plays a key role for the development of countries and is related to the level of development (Örnek \& Türkmen, 2019). Energy use and economic growth are linked. The increase in energy demand in developing countries is due to the increase in income levels. These countries also increase their production amounts to meet the needs of their populations, and the increased production amount increases their energy requirement (Wolde-Rufael, 2009). They showed that the effect of energy consumption on economic growth is that energy consumption causes economic growth in OECD countries, but vice versa, energy consumption does not cause economic growth in non-OECD countries. (Chontanawata et al., 2008). There is very little work on efficient use of energy and technological pollution (Kavaz \& Öztoprak, 2019). In their study with university organizers, found that although students have concerns about campus sustainability and the corresponding environmental benefits, they have less awareness of transportation, energy and water conservation at the camp base. It was also reported that little attention was paid to 
Erdal, N. (2020). Perceptions of health workers in effective use of energy and prevention of technological pollution. International Journal of Social Sciences and Education Research, 6(4), 543-555.

sustainability in their curricula and student projects. The study is important in terms of being a starting point for the production of comprehensive goals and strategies for the sustainability of the International University of Cyprus (CIU) campus (Kavaz \& Öztorak, 2019).

Saraç and Bedir (2014) found that teachers' perceptions about renewable energy sources were quite low. It was decided. Renewable energy sources are the only alternative that should be addressed for both sustainable development and global warming and climate change (Seydiogulları, 2013). Approaches using renewable energy sources to increase the effective use of energy have attracted great attention in recent years. Energy consumption will be reduced and renewable energy will be used in buildings where natural ventilation with chimney and chimney effect is designed by using solar and wind energy (Engin, 2011). In a similar study, energy efficiency is increased by using wind energy in buildings, and it is directed towards designs that increase physical environmental control, are environmentally friendly and use the least energy (Boduroğlu \& Karitaş, 2012).

Akmalı Özçiftçi (2010) made architectural design strategies and ecological building recommendations for the efficient use of energy in buildings in his thesis. Köklükaya and Selvi (2015) developed a scale to measure the conscious use of technological devices that cause Electromagnetic Pollution. There are few studies on this. Durusoy measured the use of mobile phones and the level of knowledge of the electromagnetic field with students in 2011. Sarıgöz et al., (2012) stated in their study on students that students had information about electromagnetic pollution. In the globalizing world, developed and developing countries follow different policies for environmental awareness. Developed countries are shifting their industries to developing countries to reduce pollution (Şahin et al, 2019).

\section{Purpose of the study}

Energy is the most important part of human life. Fossil fuels make up the largest share of the energy resources used in the world. These are not limitless, they are decreasing day by day. Today, energy policies aim not only to use less energy but also to direct them to environmentally friendly energy production, to reduce costs and to prevent technological pollution. With this work, it was carried out in order to increase the effective use of energies and to raise awareness to prevent technological pollution. It is to create a sustainable environment by creating behavioral changes with small touches in life. This study, conducted in the Marmara region in Turkey, the civil servants working in a public hospital which operates in one of the metropolitan cities and is intended to raise awareness.

\section{Method}

The sample of the study; Turkey 'also dates between January and December 2019 was conducted in a university hospital in the Marmara region with a total of 229 people consisting of employee health officials. In the study, the Efficient Use of Energy and Technological Pollution Awareness Scale developed by (Okur \& Yalçın-Özdilek, 2013) There are 16 items in the scale consisting of 5 Likert's.

\subsection{Hypotheses}

H1. There is a difference between men and women in terms of efficient use of energy and awareness of technological pollution.

H1a. There is a difference between men and women in awareness of the production of energy. 
Erdal, N. (2020). Perceptions of health workers in effective use of energy and prevention of technological pollution. International Journal of Social Sciences and Education Research, 6(4), 543-555.

H1b. There is a difference between men and women in terms of awareness of technological pollution.

H1c. There is a difference between men and women in awareness of the efficient use of energy.

$\mathrm{H} 2$. There is a difference between married and single people in terms of efficient use of energy and awareness of technological pollution.

H2a. There is a difference between married and single people in terms of awareness of the production of energy.

$\mathrm{H} 2 \mathrm{~b}$. There is a difference between married and single people in terms of awareness of technological pollution.

$\mathrm{H} 2 \mathrm{c}$. There is a difference between married and single people in terms of awareness of the efficient use of energy.

H3. There is a difference between professions in terms of efficient use of energy and awareness of technological pollution.

H4. There is a difference in terms of educational situations in terms of efficient use of energy and awareness of technological pollution.

H5. There is a difference in terms of age range of efficient use of energy and awareness of technological pollution.

\section{Findings}

Table 1. Demographic characteristics of the participants

\begin{tabular}{|c|c|c|c|c|c|}
\hline \multicolumn{7}{|c|}{ Demographic characteristics } \\
\hline Gender & Frequency & Percentage & Marital status & Frequency & Percentage \\
\hline Female & 165 & 72,1 & Married & 139 & 60,7 \\
\hline Male & 64 & 27,9 & Single & 90 & 39,3 \\
\hline Total & 229 & 100 & Total & 229 & 100 \\
\hline Age range & Frequency & Percentage & Educational situations & Frequency & Percentage \\
\hline 20 under & 1 & 0,4 & Primary School & 29 & 12,7 \\
\hline $21-30$ & 63 & 27,5 & High School & 35 & 15,3 \\
\hline $31-40$ & 75 & 32,8 & Associate degree & 36 & 15,7 \\
\hline $41-50$ & 80 & 34,9 & License & 89 & 38,9 \\
\hline $51-60$ & 10 & 4,4 & Graduate license & 34 & 14,8 \\
\hline Total & 229 & 100 & Doctorate & 6 & 2,6 \\
\hline Profession & Frequency & Percentage & Total & 229 & 100 \\
\hline Nurse & 90 & 39,3 & Profession & Frequency & Percentage \\
\hline Doctor & 8 & 3,5 & Secretary & 15 & 6,6 \\
\hline Patient care & 24 & 10,5 & Administrative officer & 38 & 16,6 \\
\hline Technician & 26 & 11,4 & Helpful staff & 28 & 12,2 \\
\hline Total & 229 & \multicolumn{5}{|c}{100} \\
\hline
\end{tabular}

According Table 1, 72.1\% of the participants in this study are women and $27.9 \%$ are men. Married rates are $60.7 \%$ and single people are $39.3 \%$. The age distribution of the employees is between the ages of $41-50$, with a maximum of $34 \%$. At least $0.4 \%$ are under 20 years old, and $10 \%$ are 51-60 years old. Educational status is highest with $38.9 \%$ undergraduate. At least 3.5 $\%$ consists of physicians. The validity and reliability of the study has been done. The research depends on its validity and reliability to be strong (Şencan, 2005). The method used to measure the reliability of the scale Cronbach's Alpha (a) examines the relationship of random samples in a variable (Cronbach, 1951). 
Erdal, N. (2020). Perceptions of health workers in effective use of energy and prevention of technological pollution. International Journal of Social Sciences and Education Research, 6(4), 543-555.

Table 2. Efficient use of energy and technological pollution scale reliability analysis

\begin{tabular}{|c|c|c|}
\hline Scale & Cronbach's Alpha & N \\
\hline Efficient use of energy and technological pollution scale &, 831 & 16 \\
\hline
\end{tabular}

Table 2, In order for a scale to be considered reliable, the Cronbach Alpha value must be 0.70 and above (K1lıç, 2016). As seen in Table 2, the Cronbach Alpha value was found to be Cronbach' $\mathrm{s}$ Alpha $=0.831$. Since this value is above 0.70 , it is considered reliable.

Table 3. Effective use of energy and validity and significance analysis of technological pollution scale

\begin{tabular}{|c|c|c|c|c|}
\hline Name of variable & $\begin{array}{c}\text { Kaiser-Meyer- } \\
\text { Olkin }\end{array}$ & $\begin{array}{c}\text { Approximately } \\
\text { chi square }\end{array}$ & $\begin{array}{c}\text { Bartlett's Sphericity } \\
\text { test Df }\end{array}$ & Sigma \\
\hline $\begin{array}{l}\text { Efficient use of energy and techno- } \\
\text { logical pollution scale }\end{array}$ & 852 & 1190,677 & 120 &, 000 \\
\hline
\end{tabular}

The Kaiser-Mayer-Olkin (KMO) sampling adequacy measurement was used to measure the suitability of the variables to the Factor analysis, and the Bartlett Sphericity test was used to measure the correlation level between variables. KMO ratio takes value between 0 and 1. Table. 3 $\mathrm{KMO}=, 852$ is considered highly valid (Kaiser, 1974). It is known as significance (Sig) in the Bartlett Test of Sphericity. The limit of this value is accepted as $<0.005$ (Hair et al.,2010). In the study, this value is significant because it is 0,000 . According to the Bartlett Sphericity test results, there is a significant correlation between all variables. Exploratory factor analysis was performed to test the validity of variables and scales that successfully passed KMO and Bartlett's Sphericity tests. The scale, which was previously examined under two subtitles as efficient use of energy and technological pollution, has been examined under three subtitles in this study. The factor loadings of the 7 and 14 questions were excluded from the study because of overlapping. With the Promax analysis, the explanation rate of the total variance was found to be $53,678 \%$.

Table 4. Exploratory factor analysis loads

\begin{tabular}{|c|c|c|c|c|}
\hline No & Rotated Component Matrix & $\begin{array}{c}\text { Energy pro- } \\
\text { duction }\end{array}$ & $\begin{array}{c}\text { Technological } \\
\text { pollution }\end{array}$ & $\begin{array}{c}\text { Efficient use } \\
\text { of energy }\end{array}$ \\
\hline 15 & Can use waste straw bales instead of wood to insulate buildings & 955 & & \\
\hline 16 & Firewood can be obtained from olive seeds & ,774 & & \\
\hline 13 & $\begin{array}{l}\text { The use of bicycles instead of driving in the city should be wide- } \\
\text { spread. }\end{array}$ & ,654 & & \\
\hline 12 & Increasing biogas production can reduce dependence on oil & ,456 & & \\
\hline 11 & $\begin{array}{l}\text { The use of wind turbines for electricity generation in windy areas } \\
\text { should be made mandatory by law. }\end{array}$ & ,436 & & \\
\hline 1 & $\begin{array}{l}\text { The rapid development of technology has brought technological } \\
\text { pollution with it. }\end{array}$ & & ,876 & \\
\hline 3 & Genetically modified foods can threaten human and animal health & & ,794 & \\
\hline 6 & $\begin{array}{l}\text { Another way to protect forests is by recycling and reusing waste } \\
\text { paper. }\end{array}$ & & 600 & \\
\hline 4 & $\begin{array}{l}\text { Every house can generate its own electricity with solar panels in } \\
\text { sunny areas. }\end{array}$ & & ,562 & \\
\hline 10 & $\begin{array}{l}\text { Recycling of waste papers can be made, as well as electronic ma- } \\
\text { terials that are not in use. }\end{array}$ & & ,443 & \\
\hline 8 & Electronic devices must be turned off from the on / off button. & & & ,705 \\
\hline 2 & $\begin{array}{l}\text { In order to keep up with the technology, mobile phones should be } \\
\text { renewed every time a new product is released }\end{array}$ & & & 700 \\
\hline 9 & Low energy consuming electronic devices should be used & & & ,607 \\
\hline 5 & Even energy can be obtained from Ocean Waves & & & ,407 \\
\hline
\end{tabular}

Extraction Method: Principal Component Analysis. Rotation Method: Promax with Kaiser Normalization. a. Rotation converged in 6 iterations

Although the effective use of energy and the technological pollution scale, which are examined in two subtitles in the scale, are normally examined in two dimensions as efficient use of energy 
Erdal, N. (2020). Perceptions of health workers in effective use of energy and prevention of technological pollution. International Journal of Social Sciences and Education Research, 6(4), 543-555.

and technological pollution, as shown in Table 4, in this study, energy production is divided into three sub-dimensions as technological pollution and efficient use of energy. Factor analysis was performed using the Promax method. Factor loadings Table. 4 shown. Questions 7 and 14 were excluded due to low factor load.

Table 5. Independent samples $\mathrm{T}$ test result for comparison of gender of participants, scale scores and sub-dimensions

\begin{tabular}{|c|c|c|c|c|c|c|c|}
\hline Scale & Gender & $\mathrm{N}$ & Mean & $\begin{array}{l}\text { Standard } \\
\text { deviation }\end{array}$ & $\mathrm{t}$ & df & $P$ \\
\hline \multirow{2}{*}{$\begin{array}{l}\text { Efficient use of energy and } \\
\text { technological pollution scale }\end{array}$} & Female & 165 & 1,7788 & ,41979 & \multirow[t]{2}{*}{,576 } & \multirow[t]{2}{*}{227} & \multirow[t]{2}{*}{,565 } \\
\hline & Male & 64 & 1,7433 & ,41508 & & & \\
\hline \multirow[t]{2}{*}{ Energy Production } & Female & 165 & 1,4715 & ,44170 & \multirow[t]{2}{*}{485} & \multirow[t]{2}{*}{227} & \multirow[t]{2}{*}{628} \\
\hline & Male & 64 & 1,5031 & ,44507 & & & \\
\hline \multirow{2}{*}{$\begin{array}{c}\text { Technological } \\
\text { pollution }\end{array}$} & Female & 165 & 1,4715 & ,44170 & \multirow{2}{*}{$\begin{array}{c}2,01 \\
1\end{array}$} & \multirow[t]{2}{*}{227} & \multirow[t]{2}{*}{046} \\
\hline & Male & 64 & 1,5031 & ,44507 & & & \\
\hline \multirow[t]{2}{*}{ Efficient use of energy } & Female & 165 & 2,1788 & ,54578 & \multirow[t]{2}{*}{485} & \multirow[t]{2}{*}{227} & \multirow[t]{2}{*}{628} \\
\hline & Male & 64 & 2,0117 & ,60982 & & & \\
\hline
\end{tabular}

According to Table .5, there was no significant difference other than technological pollution in the Independent Samples Test result between the effective use of energy and technological pollution averages and sub-dimensions of women and men. Since $p=0.046$ in the comparison of technological pollution between women and men, that is, $\mathrm{p}<=.005$, there is a significant difference. Technological pollution is higher in men than women.

Table 6. Independent samples $\mathrm{T}$ test result for comparison of marital status of participants, scale scores and sub-dimensions

\begin{tabular}{|c|c|c|c|c|c|c|c|}
\hline Scale & $\begin{array}{l}\text { Marital sta- } \\
\text { tus }\end{array}$ & $\mathrm{N}$ & Mean & $\begin{array}{r}\text { Standard } \\
\text { deviation }\end{array}$ & $\mathrm{t}$ & $\mathrm{df}$ & $\mathrm{P}$ \\
\hline \multirow{2}{*}{$\begin{array}{l}\text { Efficient use of energy and } \\
\text { technological pollution scale }\end{array}$} & Married & 139 & 1,7251 & ,03466 & \multirow{2}{*}{1,98} & \multirow{2}{*}{227} & \multirow{2}{*}{, 049} \\
\hline & Single & 90 & 1,8365 &, 04482 & & & \\
\hline \multirow[t]{2}{*}{ Energy Production } & Married & 139 & 1,7712 & ,04857 & \multirow{2}{*}{1,73} & \multirow{2}{*}{227} & \multirow{2}{*}{, 084} \\
\hline & Single & 90 & 1,9067 &, 06138 & & & \\
\hline \multirow{2}{*}{$\begin{array}{c}\text { Technological } \\
\text { pollution }\end{array}$} & Married & 139 & 2,0881 & ,56695 & \multirow{2}{*}{1,71} & \multirow{2}{*}{227} & \multirow{2}{*}{,088 } \\
\hline & Single & 90 & 2,2000 & ,56613 & & & \\
\hline \multirow[t]{2}{*}{ Efficient use of energy } & Married & 139 & 2,0881 & ,56695 & \multirow{2}{*}{1,45} & \multirow{2}{*}{227} & \multirow{2}{*}{, 014} \\
\hline & Single & 90 & 2,2000 & ,56613 & & & \\
\hline
\end{tabular}

As can be seen in Table 6, a significant difference has been observed between the averages of technological pollution and the sub-dimensions of the effective use of energy by married and single people, in terms of the effective use of energy and the average technological pollution subdimensions of the effective use of energy as a result of the Independent Samples Test. Because $p$ value $<=.005$ is a significant difference. The average of efficient use of energy and technological pollution is higher for singles than married people. Average scores of effective energy use of married people were found to be lower than singles. No significant differentiation was found regarding technological pollution and energy generation. Because $p$ values are greater than 0,05 .

Anova test was conducted to investigate whether there is a difference between educational situations and efficient use of energy and technological pollution and its sub-dimensions. As can be seen in the table, since all level homogeneity values are greater than $=0.05$, it was deemed appropriate to conduct Anova test. 
Erdal, N. (2020). Perceptions of health workers in effective use of energy and prevention of technological pollution. International Journal of Social Sciences and Education Research, 6(4), 543-555.

Table 7. Test of homogeneity of variances (educational situations)

\begin{tabular}{|c|c|c|c|c|}
\hline Scale & Levene statistic & df1 & df2 & Sig. \\
\hline Efficient use of energy and technological pollution scale &, 742 & 5 & 223 &, 593 \\
\hline Energy production &, 631 & 5 & 223 &, 676 \\
\hline Technological pollution &, 892 & 5 & 223 &, 487 \\
\hline Efficient use of energy & 1,086 & 5 & 223 &, 369 \\
\hline
\end{tabular}

Table 8. Anova results according to the education status of the participants (educational situations)

\begin{tabular}{|cc|c|c|c|c|c|}
\hline & & Sum of Squares & df & Mean Square & F & Sig. \\
\hline Efficient use of energy and & Between groups &, 813 & 5 &, 163 &, 929 &, 463 \\
technological pollution & Within groups & 39,000 & 223 &, 175 & & \\
scale & Total & 39,813 & 228 & & \\
Energy production & Between groups &, 752 & 5 &, 150 &, 443 &, 818 \\
& Within groups & 75,671 & 223 &, 339 & & \\
Technological & Total & 76,423 & 228 & &, 530 \\
pollution & Between groups &, 778 & 5 &, 156 &, 530 \\
& Within groups & 41,824 & 223 &, 188 & & \\
Efficient use of energy & Total & 42,602 & 228 & & \\
& Between groups & 3,803 & 5 &, 761 & 2,432 &, 036 \\
& Within groups & 69,763 & 223 &, 313 & & \\
& Total & 73,567 & 228 & & & \\
\hline
\end{tabular}

As can be seen in Table 8. no differentiation was found regarding educational status, the scale itself and its sub-dimensions, except for the efficient use of energy. Since the effective use of energy is sig value $=.036$, there has been a difference between educational situations and efficient use of energy.

Table 9. Test of homogeneity of variances (age range)

\begin{tabular}{|c|c|c|c|c|}
\hline Scale & Levene Statistic & df1 & df2 & Sig. \\
\hline $\begin{array}{c}\text { Efficient use of energy and technological } \\
\text { pollution scale }\end{array}$ &, $632^{\mathrm{a}}$ & 3 & 224 &, 595 \\
\hline Energy production &, $549^{\mathrm{b}}$ & 3 & 224 &, 649 \\
\hline Technological pollution & $2,442^{\mathrm{c}}$ & 3 & 224 &, 065 \\
\hline Efficient use of energy & $1,506^{\mathrm{d}}$ & 3 & 224 &, 214 \\
\hline
\end{tabular}

According to the Levene test shown in Table 9, it was deemed appropriate to perform the Anova test between the scale and its sub-dimensions. Because sig. value $>0.05$ in all scale dimensions and sub-dimensions.

Table 10. Anova results according to the education status of the participants (age rate)

\begin{tabular}{|c|c|c|c|c|c|c|}
\hline & & $\begin{array}{l}\text { Sum of } \\
\text { Squares }\end{array}$ & Df & $\begin{array}{l}\text { Mean } \\
\text { Square }\end{array}$ & $\mathrm{F}$ & Sig. \\
\hline \multirow{3}{*}{$\begin{array}{l}\text { Efficient use of energy } \\
\text { and technological pollu- } \\
\text { tion scale }\end{array}$} & Between groups & ,627 & 4 &, 157 & ,481 & ,749 \\
\hline & Within groups & 72,940 & 224 & ,326 & & \\
\hline & Total & 73,567 & 228 & & & \\
\hline \multirow[t]{3}{*}{ Energy production } & Between groups &, 747 & 4 &, 187 & 1,071 &, 371 \\
\hline & Within groups & 39,065 & 224 &, 174 & & \\
\hline & Total & 39,813 & 228 & & & \\
\hline \multirow{3}{*}{$\begin{array}{c}\text { Technological } \\
\text { pollution }\end{array}$} & Between groups & 1,657 & 4 & ,414 & 1,241 & 294 \\
\hline & Within groups & 74,766 & 224 &, 334 & & \\
\hline & Total & 76,423 & 228 & & & \\
\hline \multirow[t]{3}{*}{ Efficient use of energy } & Between groups & ,768 & 4 &, 192 & 1,028 & ,393 \\
\hline & Within groups & 41,834 & 224 &, 187 & & \\
\hline & Total & 42,602 & 228 & & & \\
\hline
\end{tabular}

Copyright (C) by International Journal of Social Sciences and Education Research ISSN: 2149-5939 
Erdal, N. (2020). Perceptions of health workers in effective use of energy and prevention of technological pollution. International Journal of Social Sciences and Education Research, 6(4), 543-555.

According to Table 10, there was no significant difference between the age range and scale size and sub-dimensions. Because all of them have sig value $>0.05$

Table 11. Test of homogeneity of variances (profession)

\begin{tabular}{|c|c|c|c|c|}
\hline Scale & Levene Statistic & df1 & df2 & Sig. \\
\hline Efficient use of energy and technological pollution scale &, $332^{\mathrm{a}}$ & 6 & 221 &, 920 \\
\hline Energy production &, $667^{\mathrm{b}}$ & 6 & 221 &, 676 \\
\hline Technological pollution &, $778^{\mathrm{c}}$ & 6 & 221 &, 588 \\
\hline Efficient use of energy &, $788^{\mathrm{d}}$ & 6 & 221 &, 580 \\
\hline
\end{tabular}

According to the Levene test shown in Table 11, it was deemed appropriate to perform the Anova test between the scale and its sub-dimensions. Because sig. Value $>0.05$ in all scale dimensions and sub-dimensions.

Table 12. Anova results according to the education status of the (profession)

\begin{tabular}{|cc|r|r|r|r|r|}
\hline & & Sum of & \multicolumn{1}{c|}{ df } & \multicolumn{1}{c|}{$\begin{array}{c}\text { Mean } \\
\text { Square }\end{array}$} & \multicolumn{1}{c|}{ Sig. } \\
\hline Efficient use of energy and techno- & Between groups & 3,259 & 7 &, 466 & 1,464 &, 181 \\
logical pollution scale & Within groups & 70,307 & 221 &, 318 & & \\
& Total & 73,567 & 228 & & \\
Energy production & Between groups &, 976 & 7 &, 139 &, 794 &, 593 \\
& Within groups & 38,836 & 221 &, 176 & & \\
& Total & 39,813 & 228 & & \\
Technological & Between groups & 3,276 & 7 &, 468 & 1,414 &, 201 \\
pollution & Within groups & 73,147 & 221 &, 331 & & \\
& Total & 76,423 & 228 & & \\
Efficient use of energy & Between groups & 1,797 & 7 &, 257 & 1,390 &, 211 \\
& Within groups & 40,805 & 221 &, 185 & & \\
\hline
\end{tabular}

According to Table 12, there is no significant difference between occupation and efficient use of energy and technological pollution scale and all its sub-dimensions. Sig. value $>0.05$.

Table. 13 Results of the Hypotheses

\begin{tabular}{|c|l|c|}
\hline No & \multicolumn{1}{|c|}{ Hypothesis } & Result \\
\hline H1 & $\begin{array}{l}\text { There is a difference between men and women in terms of efficient use of } \\
\text { energy and awareness of technological pollution }\end{array}$ & Rejection \\
\hline H1a & $\begin{array}{l}\text { There is a difference between men and women in awareness of the pro- } \\
\text { duction of energy }\end{array}$ & Rejection \\
\hline H1b & $\begin{array}{l}\text { There is a difference between men and women in terms of awareness of } \\
\text { technological pollution }\end{array}$ & Reception \\
\hline H1c & $\begin{array}{l}\text { There is a difference between men and women in awareness of the effi- } \\
\text { cient use of energy. }\end{array}$ & Rejection \\
\hline H2 & $\begin{array}{l}\text { There is a difference between married and single people in terms of effi- } \\
\text { cient use of energy and awareness of technological pollution }\end{array}$ & Reception \\
\hline H2a & $\begin{array}{l}\text { There is a difference between married and single people in terms of aware- } \\
\text { ness of the production of energy. }\end{array}$ & Rejection \\
\hline H2b & $\begin{array}{l}\text { There is a difference between married and single people in terms of aware- } \\
\text { ness of technological pollution. }\end{array}$ & Rejection \\
\hline H2c & $\begin{array}{l}\text { There is a difference between married and single people in terms of aware- } \\
\text { ness of the efficient use of energy. }\end{array}$ & Reception \\
\hline H3 & $\begin{array}{l}\text { There is a difference between married and single people in terms of aware- } \\
\text { ness of the production of energy. }\end{array}$ & Partial Reception \\
\hline H4 & $\begin{array}{l}\text { There is a difference in terms of educational situations in terms of efficient } \\
\text { use of energy and awareness of technological pollution }\end{array}$ & Rejection \\
\hline H5 & $\begin{array}{l}\text { There is a difference in terms of age range of efficient use of energy and } \\
\text { awareness of technological pollution }\end{array}$ & Rejection \\
\hline
\end{tabular}

Copyright $@$ by International Journal of Social Sciences and Education Research 
Erdal, N. (2020). Perceptions of health workers in effective use of energy and prevention of technological pollution. International Journal of Social Sciences and Education Research, 6(4), 543-555.

\section{Result}

Energy is a strategic issue that needs to be considered and planned well. It should be considered technically, socially and economically, and is also an issue that determines international relations and is important for sustainable development. Countries adopt various policies to plan their reserves, production and consumption well. These policies should be in line with technological research and developments that include the changes in the world. The determining factor in today's energy policies is not to save energy, but to produce economical, environmentally friendly, renewable energy in energy production. The fact known by everyone is that energy is produced at the least cost, used efficiently and saved. One of the things that should not be forgotten here is the utilization of waste energies and the prevention of losses in the available energy. Energy gained by saving is cheaper than energy obtained from new energy sources.

One of the most important issues of today is environmental technologies and cleaner production. These include technological innovations for minimal energy, water, raw material consumption and waste generation and can be used in industry. These cleaner production technologies with economic values are known as environmental technologies. The use of this cleaner production as an environmental strategy in products and processes reduces the risks in the environment. It ensures that environmental problems are prevented before they occur. Because after the pollution occurs, additional costs are required to eliminate them. Clean, sustainable production, resource efficiency, prevention of pollution at the source, environmentally friendly product, etc. that are possible with the development and use of environmental technologies. provides businesses with a reduction in production costs apart from social benefits.

This study was carried out in order to use energy resources effectively and efficiently, to know what renewable energies are, to save energy by creating changes in life, to adopt sustainable energy policies, to use technology not as pollution but as a factor to reduce energy and pollution. Energy, technology and pollution are interrelated for the future of our country and the world. Good planning of this triangle is important for the future of the world. The scale used for efficient use of energy and technological pollution is sufficient. Its validity, reliability and significance level were found to be quite high. While the scale, whose validity and reliability were conducted by (Okur \& Yalçı-Özdilek, 2013), was examined in two sub-dimensions, it was divided into three sub-dimensions according to this study.

Environment is an issue that concerns both men and women. Whether men or women, all people have to efficiently use energy resources that are limited to nature and reduce technological pollution. Because nature was not created solely for human beings to survive, and it enables many living things to live. Therefore, efficient use of energy and prevention of technological pollution are important issues for a livable world. In this study, although there was no significant difference between men and women in terms of efficient use of energy and prevention of technological pollution, a difference was observed in the technological pollution sub-dimension of men and the average scores of men were higher than women. In terms of age range, education level and profession, no significant differentiation was found for efficient use of energy and prevention of technological pollution. In other words, all field employees use energy effectively and try to prevent technological pollution. A difference was observed in terms of education levels only in efficient use of energy.

Based on these data, various in-service trainings, symposiums, congresses should be organized in order to increase environmental awareness, to use energy effectively, to prevent technological pollution and to raise awareness. The use of renewable energies should be preferred in 
Erdal, N. (2020). Perceptions of health workers in effective use of energy and prevention of technological pollution. International Journal of Social Sciences and Education Research, 6(4), 543-555.

workplaces. The infrastructure required for renewable energies should be planned and transportation should be easy and cheap. New habits and measures that consumers will adopt in their daily lives will both reduce the use of energy resources and contribute to their family budgets. Small arrangements to be made at home and in the working environment will ensure efficient use of energy. For example; unplugging electronic devices, regularly maintaining radiators and comb boilers, using smart meters, etc. While the advancement of technology has increased energy consumption, thanks to technology, environmentally friendly and less energy-consuming items have been produced. White goods that we use in our daily lives and make our lives easier have become smart. If you need to change your white goods, you should choose the new generation smart white goods.

Starting from the projecting stage of commercial buildings, air conditioning (heating / cooling) and lighting functions are primarily regulated by building automation systems is optimized. Thus, from the installation stage, a serious energy saving / efficiency is provided, including usage. On the other hand, this type of work is not yet common enough in residences. Therefore, it is up to us to save energy in our homes. It shows that we can achieve great results with small efforts in daily life. In order to keep electromagnetic pollution at the lowest level,

There are very few studies on efficient use of energy, technological pollution and the environment. Energy and pollution are very important issues for the continuation of life and a sustainable life. Necessary sensitivity should be shown to such studies, people's sensitivity to the environment should be increased. Necessary information, symposiums, congresses should be done, and global solutions should be found to environmental problems. Environmental studies have mostly been done with organizers, and studies should be done with other people.

\section{References}

Akmalı Özçiftçi, S.( 2010). Ekolojik Binalarda Enerjinin Etkin Kullanılmasının İrdelenmesi, Dokuz Eylül Üniversitesi, Fen Bilimleri Enstitüsü Yükseklisans Tezi, İzmir.

Atalay, İ. (2013). Doğa Bilimleri Sözlüğü. Meta Basım ve Matbaacılık, İzmir.

Boduroğlu, Ş \& Kariptaş, F (2012). Rüzgar Enerjili Etkin Sistemlerin Yapılarda Kullanım Biçimleri, Green Age Symposium, Mimar Sinan Fine Arts University 26-27 Nisan 2012, İstanbul, Türkiye.

Bruntland, G. (1987). Our Common Future: The World Commission on Environment and Development, Oxford, Oxford University Pres.

Chontanawata J., Hunta L.C. \& Pierseb R., (2008). Causality Between Energy Consumption and Economic Growth in OECD and NonOECD Countries: A Panel Data Approach, Int. Assoc for Energy Economics.

Cronbach, L, J. (1951). Coefficient Alpha And The International Structure of Tests, Psychometrika, 16 (3)

Çerezci, O. \& Yener, Ş. Ç. (2016). Çevremizdeki Elektromanyetik Kirlilik ve Sağlı̆ğımıza Etkileri ISEM2016, 3rd International Symposium on Environment and Morality, 4-6 Nov 2016, Alanya,Turkey

Çınar Doğu, S. \& Meydan, A. (2008). Sınıf Öğretmeni Adaylarının Çevreye Karşı Tutumları, VII. Ulusal Sınıf Öğretmenliği Eğitimi Sempozyumu (2-4 Mayıs), Nobel Yayın Dağıtım, Ankara

Dağdemir Ö. (2015). Çevre Sorunlarına Ekonomik Yaklaşımlar ve Optimal Politika Arayışları, Gazi Kitabevi, Ankara.

Engin. N.( 2011). Enerji Etkin Tasarımda Pasif İklimlendirme: Doğal Havalandırma, X .Ulusal Tesisat Mühendisliği Kongresi,13/ 16 Nisan 2011

Erdal,N., Tayran,N., Kaçar,S., Kodaloğlu K. \& Turfan,G. ( 2020). Çevreye Karşı Duyarlılık: Sağlık Çalışanı Ve Hasta Yakını Örneği, Avrasya Sosyal ve Ekonomi Araştırmaları Dergisi, 7 ( 6): 278-298. 
Erdal, N. (2020). Perceptions of health workers in effective use of energy and prevention of technological pollution. International Journal of Social Sciences and Education Research, 6(4), 543-555.

Es, M. (1995). Teknoloji, Kalkınma ve Çevre, Teknoloji, Kalkınma ve Çevre Sosyal Siyaset Konferansları Dergisi : 290-301 https://dergipark.org.tr/tr/download/article-file/9555

Gladwin, T.N., Kennelly, J.J. \& Krause, T-S., (1995). Shifting Paradigms for Sustainable Development: Implications for Management Theory and Research, Academy of Management 20(4): 874-907.

Hair,J., Black, W.\& Babin BJ. ( 2010). Multivariate Data Analysis, New Jersey, Pearson Higher Education,

Hill, S. D.\& Thompson, D. (2006). Understanding Managers Views of Global Environmental Risk. Environmental Management, 37( 6): 773- 787

Kahraman, G. ( 2019). Türkiye'de Kentleşmenin Enerji Tüketimi ve Karbon Salınımı Üzerine Etkisi, Iğdır Üniversitesi Fen Bilimleri Enstitüsü Dergisi, 9(3): 1559-1566

Kaiser, H, F. ( 1974). An Index Of Factorial Simplicity, Psychometrica,38(1):31-36

Kaiser, F. G., Wölfing, S.\& Fujrer, U. (1999). Environmental attitudes and ecological behaviour.Journal of Environmental Psychology,19: 1-19.

Kavaz, D \& Öztoprak, H. (2019).Sürdürülebilir Kalkınma Farkındalığı ve Çevresel Duyarlılık Üzerine Bir Durum Çalışması: Uluslararası Kıbrıs Üniversitesi Folklor/edebiyat, 25( 97-1): 145-166

Kete,H., Aydın,M.S \& Kaya,H.( 2017). Çevre Sorunları İle Mücadelede Maliye Politikaları, Journal of Life Ecomnomics, 167-190

Kılıç, S. (2016). Cronbach'ın Alfa Güvenilirlik Katsayısı, Journal Of Mood Disore- ,6 (1): 47-48

Kızılboğa R. \& Batal S. (2012), Türkiye'de Çevre Sorunlarının Çözümünde Yerel Yönetimlerin Rolü ve Önemi, Mustafa Kemal Üniversitesi Sosyal Bilimler Enstitüsü Dergisi,9(20): 191-212

Nalçacı, A., \& Beldağ, A. (2012). İlköğretim 7. ve 8. Sınıf Öğrencilerinin Çevre Tutumlarının Belirlenmesi (Erzurum Örneği). Doğu Coğrafya Dergisi, 28, 141-154

Okur, E., \& Yalçın Özdilek ,Ş. ( 2013). Enerjinin Etkin Kullanımı Ve Teknolojik Kirlilik Farkındalık Ölçeği, Kastamonu Eğitim Dergisi ,21(1): 271-286

Örnek, İ.\& Türkmen, S. (2019). Gelişmiş Ve Yükselen Piyasa Ekonomilerinde Çevresel Kuznets Eğrisi Hipotezi'nin Analizi, Çukurova Üniversitesi Sosyal Bilimler Enstitüsü Dergisi, 28,(3): 109-129.

Örselli,E.\& Akbay,C.( 2019).Teknoloji ve Kent Yaşamında Dönüşüm: Akıllı Kentler Uluslar arası Yönetim akademisi Dergisi,2(1): 228-241

Özkoçak, V., Akın,G.. \& Timur Gültekin,T.( 2017). Ergonomik Açıdan İnsanın Tarih Öncesi Ve Sonrası Teknolojileri İle Ürünlerinin Karşılaştırılması, Journal of Engineering Sciences and Design 5 (SI: Ergonomi 2016): 167-173, 2017 DOI: 10.21923/jesd.44122

Saraç, E \& Bedir, H.(20014). Sınıf Öğretmenlerinin Yenilenebilir Enerji Kaynakları İle İlgili Algılamaları Üzerine Nitel Bir Çalı̧̧ma, KHO Bilim Dergisi,24 (1): 19- 45

Sarıgöz,A., Karakuş, A. \& Irak, K.( 2012).Meslek Yüksekokulu Öğrencilerinin Elektromanyetik Kirlilik ile İlgili Görüşlerinin Değerlendirilmesi, Electronic Journal of Vacational Collages ,2(2): 1-8

Sarıkaya, M. ve Kara, F. Z., (2007), Sürdürülebilir Kalkınmada İșletmenin Rolü: Kurumsal Vatandaşlık, Celal Bayar Üniversitesi İ̈BF, Yönetim ve Ekonomi, 14(2): 221-233.

Seydioğulları,S.H.( 2013). Sürdürülebilir Kalkınma İçin Yenilenebilir Enerji, Planlama, 23(1) : 19-25

Sahin, G , Gökdemir, L , Ayyıldız, F . (2019). Türkiye Örneğinde Kirlilik Sığınağı Ve Kirlenme Hale Hipotezleri Üzerine Ampirik Bir Araştırma. Süleyman Demirel Üniversitesi Sosyal Bilimler Enstitüsü Dergisi, 2 (33): 104-140.

Şencan, H. (2005). Sosyal ve Davranışsal ölçümlerde Güvenilirlik ve Geçerlilik, 1 Baskı, Ankara

Wolde-Rafuel Y. (2009). Energy consumption and economic growth: The experience of African countries revisited, Energy Economics, 31 ( 2):217-224

Yılmaz, A., Bozkurt, Y. ve Taşkın, E. (2005). Doğal Kaynakların Korunmasında Çevre Yönetiminin Etkinliği, D.P.Ü. Sosyal Bilimler Enstitüsü Dergisi,194.27.234.108

------ https://cevreonline.com

----- http://www.kutahyaninsesi.com

Copyright (C) by International Journal of Social Sciences and Education Research ISSN: 2149-5939 